\title{
IMPROVEMENT OF YIELD AND QUALITY OF ROSELLE (HIBISCUS SABDARIFFA L.) PLANT BY USING NATURAL SOURCES OF PHOSPHORUS AND POTASSIUM IN CALCAREOUS SANDY SOILS
}

\author{
A.A.S. Abdel-Kader and F.E.M. Saleh \\ Medicinal and Aromatic Plants Research Department, Horticulture Research Institute, \\ Agricultural Research Center (ARC), Giza, Egypt
}

\begin{abstract}
Two separate field experiments were conducted during 2013 and 2014 to study the effects of natural sources of phosphorus and potassium fertilizers as rock phosphate (RP) and feldspar (F) with or without biofertilizers comparing with chemical fertilizer (PK) on growth, yield and quality characteristics of roselle (Hibiscus sabdariffa L.) plant. The first experiment included phosphorus treatments (at different levels of rock phosphate; 150, 200 and $250 \mathrm{~kg} / \mathrm{fed}$ ) and the second one included potassium treatments (at different levels of feldspar; 250, 350 and $450 \mathrm{~kg} / \mathrm{fed}$ ), each comparing with recommended dose of chemical PK. The obtained results revealed that co-inoculation of PDB (Bacillus megaterium var. phosphaticum) and KDB (Bacillus mucilaginosus) in conjunction with direct application of rock phosphate at rates of 200 and $250 \mathrm{~kg} /$ fed and feldspar at rates of 350 and $450 \mathrm{~kg} /$ fed respectively, into the soil significantly increased the growth characteristics under the study (plant height, number of branches/plant, fresh and dry weight/plant,) along with yield (number of fruits/plant, fresh weight of fruit/plant, fresh and dry weight of sepals/plant, weight of seeds g/plant and weight of dry sepals $\mathrm{kg} / \mathrm{fed}$ ) comparing to chemical PK and other treatments. The highest growth and yield were obtained from plants treated with $200 \mathrm{~kg} / \mathrm{fed}$ rock phosphate plus PDB in the first experiment and $350 \mathrm{~kg} / \mathrm{fed}$ feldspar plus KDB in the second experiment. While PK treatment resulted in the highest acidity \% and total anthocyanin content of dry sepals as compared to all the other treatments in the first and second seasons. Generally, the results suggest that the use of biofertilizer with rock phosphate or with feldspar are economical, environmental friendly and have potential to improve roselle yield and quality.
\end{abstract}

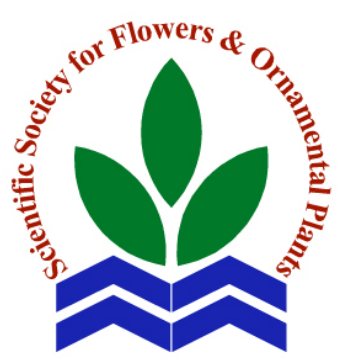

Scientific J. Flowers \& Ornamental Plants, 4(3):233-244 (2017).

Received:

9/12/2017

Accepted:

22/12/2017

Key words: Rock phosphate, roselle, feldspar and biofertilizer.

\section{INTRODUCTION}

The genus Hibiscus is an annual herbaceous shrub belonging to the family Malvacea. True roselle is $H$. sabdariffa L., of which there are two main types. $H$. sabdariffa var. altissima Wester. and $H$. sabdariffa var. sabdariffa (Morton, 1974). The roselle plant cultivated mainly for its flowers. Seeds and leaves have some uses in traditional medicine for relief of sour throat and for healing wounds as an anti-septic (Eltayeib and Hamade, 2014). Also has been to be folk treatment for cancer, obesity, diabetes and hypertension (Osuntgum and Aboaba, 2004). The crop has been gaining importance in the manufacture of many small industries, e.g. jams, jellies, sweet, sauces and cosmetic and also used as a coloring material for food and beverages. 


\section{A.A.S. Abdel-Kader and F.E.M. Saleh}

Plant nutrients are a vital component of sustainable agriculture. Increased crop production largely relies on the type of fertilizers used to supplement essential nutrients for plants. Phosphorus and Potassium are essential nutrients for crop growth and development among the macronutrients. Most of the tropical soils are known to have low phosphorus status (Balasubramanian et. al., 1978; Adepetu, 1986). Inclusion of phosphorus fertilizers in any crop fertilization program is therefore very important for these soils. Since, application of chemical fertilizers increase the soil and water pollution and accumulation of some heavy metals such as cadmium, they can threat the human health. Therefore, the use of locally-available alternatives, such as indigenous rock phosphate (RP) and feldspar is now being advocated. From direct application of RP as a $\mathrm{P}$ source to the soils, it has been clearly found that this approach is feasible for the acidic soils and beneficial to crops (Caravaca et al., 2004 and Akande et al., 2008). Also potassium is essential in all cell metabolic processes. Consequently, $\mathrm{K}$ deficiencies become a problem because $\mathrm{K}$ decreases easily in soils due to crop uptake, run off, leaching and soil erosion (Sheng and Huang, 2002). Direct application of rock phosphate (RP) and potassium (RK) materials may be agronomically more useful and environmentally more feasible than soluble $\mathrm{P}$ and $\mathrm{K}$ (Ranawat et al., 2009). Rock $\mathrm{P}$ and $\mathrm{K}$ materials are cheaper sources of $\mathrm{P}$ and $\mathrm{K}$; however, most of them are not readily available to a plant because the minerals are released slowly and their use as fertilizer often causes insignificant yield increases of current crop (Zapata and Roy, 2004). The use of plant growth promoting rhizobacteria (PGPR), including phosphate and potassium dissolving bacteria (PDB and $\mathrm{KDB}$ ) as biofertilization, was suggested as a sustainable solution to improve the plant growth and plant nutrition.

Bio-fertilizers containing beneficial bacteria and fungi improve soil chemical and biological characteristics, and agricultural production (El-Habbasha et al., 2007; Yosefi et al., 2011). On the other hand, use of biofertilization on Egyptian soils has decreased the $\mathrm{pH}$, which had led to increased availability of trace elements that enhance plant growth (Mahfouz and Sharaf-Eldin, 2007).

Some bacteria provide plants with growth promoting substances and play major role in phosphate solubilizing (Abou-Aly et al., 2006). Phosphate solubilizing bacteria have been used to improve rock $P$ value because they convert insoluble rock $\mathrm{P}$ into soluble forms available for plant growth (Nahas et al., 1990; Shivay, 2010). This conversion is through acidification, chelation and exchange reactions (Gerke, 1992) and produces, in the periplasm, strong organic acids (acetate, lactate, oxalate, tartarate, succinate, citrate, gluconate, ketogluconate, glycolate, etc.) reduce the $\mathrm{pH}$ of the microenvironment prevailing around these microbes (Alexander, 1997; Puente et al., 2004 and Parassana et al., 2011). Bacillus megaterium var. phosphaticum is known for its ability to solubilize rock $\mathrm{P}$ material (Rodriguez and Fraga, 1999). Potassium dissolving bacteria is an aerobic bacteria which play an important role in maintaining soil structure by their contribution in the formation and stabilization of water-stable soil aggregates (Zakaria, 2009). In addition, KSB are able to solubilize rock $\mathrm{K}$ mineral powder, such as micas, illite and orthoclases (feldspar), also through production and excretion of organic acids or chelatesilicon ions to bring the $\mathrm{K}$ into solution (Friedrich et al., 1991; Ullman et al., 1996). It was shown that KSB, such as Bacillus mucilaginosus, increased $\mathrm{K}$ availability in soils and increased mineral content in plant (Sheng et al., 2002; Zakaria, 2009). An integrated application of rock $\mathrm{P}$ and $\mathrm{K}$ materials with co-inoculation of bacteria that solubilize them might provide faster and continuous supply of $\mathrm{P}$ and $\mathrm{K}$ for optimal plant growth (Girgis, 2006; Eweda et al., 2007).Therefore the objective of this study was to evaluate the effectiveness of Rock Phosphate as (RP) as phosphorus source and feldspar as 
potassium source amended with biofertilizers on the growth, yield and quality of roselle.

\section{MATERIALS AND METHODS}

The present investigation was carried out at the experimental farm of Agricultural Research Station, Arab-El-Awamer, Assiut Governorate, Egypt, during the two successive seasons of 2013 and 2014 to evaluate the effects of soil fertilization with rock phosphate and feldspar materials (supplied by Al Ahram mining and natural fertilizer company in Egypt.) and coinoculation with Phosphate dissolving bacteria (PDB), Bacillus megatherium and potassium dissolving bacteria (KDB) Bacillus mucilaginosus (were obtained from Central lab. of Organic Agriculture, Agricultural Research Center, Giza, Egypt) on the improvement growth, yield and quality of roselle (Hibiscus sabdariffa) under limited $\mathrm{P}$ and $\mathrm{K}$ soil conditions. There were two experimental parts, consisting of rock phosphate as phosphorus source and feldspar as potassium source were applied as alternatives for chemical PK fertilizers. The layout of the experiments was a randomized complete block design (RCBD) with three replications. Pre-crop soil samples from surface soil (0-30 cm depth) were taken for chemical and physical analyses. The soil of the experimental field was calcareous sandy soil and its characteristics are presented in Table (1) which was done according to the methods described by Black et al. (1982) and Jackson (1973). Plot size was 2.5 m x 1.5 m comprising two rows of $60 \mathrm{~cm}$ apart with plant spacing $50 \mathrm{~cm}$ between each two hills cultivated on both sides of the ridge. Five seeds of local variety (Sabhia 17 dark) of roselle (obtained from the Medicinal and Aromatic Plants Research Department, Horticulture Research Institute, Egypt) were placed in each hole. After one month, the plants were thinned at one plant per hill. There were two separate experiments contained nine treatments. The recommended dose of PK chemical fertilizers used in this experiment according to the ministry of agriculture, Egypt, as chemical fertilizer treatment (200 kg/fed super phosphate $15.5 \% \quad \mathrm{P}_{2} \mathrm{O}_{2}$ and $75 \mathrm{~kg} / \mathrm{fed}$ potassium sulphate $20.5 \% \quad \mathrm{~K}_{2} \mathrm{O}$ ), $\mathrm{RP} 1+\mathrm{PDB}$, RP2+PDB, RP3+PDB, RP2 (Egyptian rock phosphate applied as an alternative for chemical $\mathrm{P}$ plus phosphate dissolving bacteria) and F1+KDB, F2+KDB, F3+KDB and F2 (Feldspar applied as an alternative for chemical $\mathrm{K}$ plus potassium dissolving bacteria) as shown in Table (2).

A comparison was made between using chemical and natural fertilizer mixtures with or without biofertilizers. All phosphorus and potassium treatments were added in the soil at planting time, while nitrogen source fertilization was applied for all treatments as ammonium sulphate $20.5 \%$ at the rate of 300 $\mathrm{kg} / \mathrm{fed}$ at 3 doses (after thinning, then at monthly intervals, the biofertilizers used inocula were added at three times in season (200 g powder/100 L water as recommended) at the rate of $600 \mathrm{~g} / \mathrm{fed}$, each carrier inoculum contains $10^{9} \mathrm{cfu} / \mathrm{g}$.

Table 1. The physical and chemical characteristics of soil prior to experimentation.

\begin{tabular}{|c|c|c|c|}
\hline Soil Properties & Values & Soil Properties & Values \\
\hline Particle size distribution & & Soluble cations $\left(\right.$ mmolc $\left.^{-1}\right)$ : & \\
\hline Sand (\%) & 89.9 & $\mathrm{Ca}^{++}$ & 3.4 \\
\hline Silt (\%) & 7.1 & $\mathrm{Mg}^{++}$ & 2.54 \\
\hline Clay (\%) & 3.0 & $\mathrm{Na}^{+}$ & 9.1 \\
\hline Soil texture & Sandy & $\mathrm{K}^{+}$ & 0.96 \\
\hline Field capacity (\%) & 10.9 & Soluble anions (mmolc $\mathrm{L}^{-1}$ ): & \\
\hline Water saturation (\%) & 23.3 & $\mathrm{CO}_{3}^{-} \mathrm{HCO}_{3}^{-}$ & 8.7 \\
\hline Total CaCO3 $\left(\mathrm{g} \mathrm{kg}^{-1}\right)$ & 300 & $\mathrm{Cl}^{-}$ & 6.1 \\
\hline EC mmhos/cm soil water extract, $1: 1$ & 1.6 & $\mathrm{SO}_{4}^{--}$ & 1.2 \\
\hline pH (1 : 1 water suspension) & 8.46 & Available potassium (mg kg ${ }^{-1}$ ) & 54.6 \\
\hline Organic matter ( $\mathrm{g} \mathrm{kg}^{-1}$ soil) & 2.4 & Available Phosphorus (mg kg${ }^{-1}$ ) & 10.75 \\
\hline Total nitrogen $\left(\mathrm{mg} \mathrm{kg}^{-1}\right)$ & 130 & & \\
\hline
\end{tabular}




\section{A.A.S. Abdel-Kader and F.E.M. Saleh}

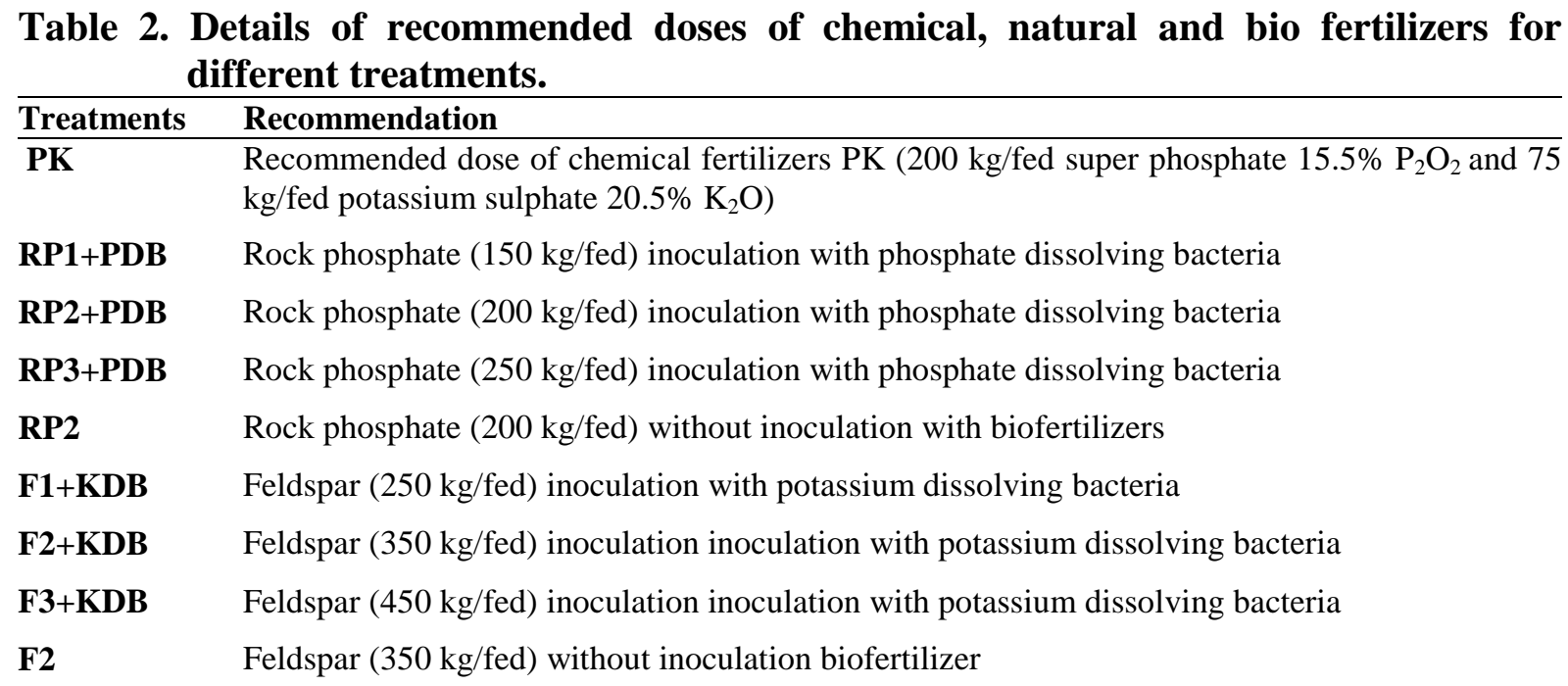

RP: Rock phosphate, F: Feldspar, PDB: Phosphate dissolving bacteria, and KDB: Potassium dissolving bacteria.

All of the other agricultural practices were applied as usual. At the harvesting, five plants were selected from the middle rows of each plot and tagged for plant height $(\mathrm{cm})$, number of branches/plant, fresh and dry weight (g/plant), number of calyces/plant, fresh weight of fruit/plant, fresh and dry weight of sepals (g/plant), weight of seeds $\mathrm{g} /$ plant and weight of dry sepals $\mathrm{kg} / \mathrm{fed}$ as well as acidity $\%$ and total anthocyanin content (mg/g) of dry sepals were measured. The extraction of the total anthocyanin pigments of the dry sepals were done by using ethyl alcohol according to the method described by Tribor and Francis (1968) and the total anthocyanin content was determined according to the method of Fuleki and Francis (1968), developed by Due and Francis (1973).

Dry sepals were used to prepare extract (0.2 g of dry sepals $/ 100 \mathrm{ml}$ of tap water) in which the acidity $(\mathrm{pH})$ as citric acid was determined as described by Diab (1968).

\section{Statistical analysis:}

Data were statistically analyzed by using F test according to Snedecor and Cochran, (1973) and Least Significant Difference (LSD) test was applied at 5\% probability level to compare the means of various treatments according to Steel and Torrie (1982).

\section{RESULTS AND DISCUSSION}

\section{1- Phosphorus fertilization experiment:}

\section{a- Effect of Rock phosphate (RP) on growth of roselle:}

The data in Table (3) showed that all treatments of rock Phosphate inoculated with PDB fertilizers significantly increased vegetative growth characters as compared to RP without biofertilizers and chemical fertilizers in both cultivated seasons. The highest plant height, root length, number of branches, number of fruits and weight of fresh and dry plant $(178.73 \mathrm{~cm}, 44.90,25.03$, 98.37, 964.0 and $209.97 \mathrm{~g} /$ plant respectively) was achieved by application of PDB with 200 kg/fed rock phosphate. The lowest values were obtained from the RP without PDB treatment in both seasons. Han et al. (2006) found that combined PSB (phosphate solubilizing bacteria) inoculation with application of rock $\mathrm{P}$ consistently increased shoot and root dry weight as compared to control. On the other hand, application of RP combined with PDB resulted in increase of $\mathrm{P}$ uptake by about $89 \%$ compared with RP alone, this might be explained that these bacteria have been used to convert insoluble rock $\mathrm{P}$ material into soluble forms to be available for plant growth (Nahas et al., 1990). Ibrahim et al. (2010) attributed the increase in the growth of the biofertilized 
Table 3. Effect of chemical and rock phosphate fertilizers with or without bio-fertilizers on plant height, root length, number of branches/plant, number of fruits/plant and weight of fresh and dry plant/plant of Hibiscus sabdariffa L. during 2013 and 2014 seasons.

\begin{tabular}{|c|c|c|c|c|c|c|c|c|c|c|}
\hline \multirow{2}{*}{ Treatments } & \multicolumn{2}{|c|}{ Plant height (cm) } & \multicolumn{2}{|c|}{ Root length(cm) } & \multicolumn{2}{|c|}{$\begin{array}{c}\text { Number of } \\
\text { branches/plant }\end{array}$} & \multicolumn{2}{|c|}{$\begin{array}{l}\text { Plant fresh weight } \\
\text { (g/plant) }\end{array}$} & \multicolumn{2}{|c|}{$\begin{array}{l}\text { Plant dry weight } \\
\text { (g/plant) }\end{array}$} \\
\hline & $\begin{array}{c}\text { Season } \\
1\end{array}$ & $\begin{array}{l}\text { Season } \\
2 \\
\end{array}$ & $\begin{array}{c}\text { Season } \\
1\end{array}$ & $\begin{array}{c}\text { Season } \\
2 \\
\end{array}$ & $\begin{array}{c}\text { Season } \\
1\end{array}$ & $\begin{array}{c}\text { Season } \\
2\end{array}$ & $\begin{array}{c}\text { Season } \\
1\end{array}$ & $\begin{array}{c}\text { Season } \\
2 \\
\end{array}$ & $\begin{array}{c}\text { Season } \\
1\end{array}$ & $\begin{array}{c}\text { Season } \\
2 \\
\end{array}$ \\
\hline PK & 169.60 & 172.00 & 35.64 & 36.60 & 21.83 & 19.07 & 893.33 & 891.33 & 195.33 & 191.57 \\
\hline RP1+PDB & 168.17 & 170.90 & 34.77 & 36.70 & 21.13 & 20.37 & 885.00 & 868.67 & 193.53 & 189.17 \\
\hline RP2+PDB & 178.73 & 176.67 & 44.90 & 44.83 & 23.73 & 25.03 & 964.00 & 953.00 & 209.97 & 200.63 \\
\hline RP3+PDB & 176.73 & 173.47 & 34.10 & 36.53 & 22.70 & 22.83 & 960.67 & 913.67 & 208.27 & 199.27 \\
\hline RP2 & 166.07 & 166.00 & 34.67 & 32.77 & 19.07 & 18.90 & 830.33 & 826.33 & 180.60 & 179.37 \\
\hline L.S.D.at5\% & 4.42 & 3.77 & 2.32 & 1.63 & 2.51 & 2.07 & 11.90 & 50.45 & 3.33 & 4.92 \\
\hline
\end{tabular}

RP: Rock phosphate, F: Feldspar, PDB: Phosphate dissolving bacteria, and KDB: Potassium dissolving bacteria.

trees due to the ability of $B$. megaterium to produce some growth promoting substances such as IAA, gibberellins and abscisic acid, it is also well known that $B$. megaterium produces organic, inorganic acids and $\mathrm{CO}_{2}$, which lead to increase in soil acidity and consequently convert the insoluble forms of phosphorus into soluble ones.

\section{b- Effect of rock phosphate (RP) on the yield of roselle:}

The effect of natural phosphate fertilizer (RP) amended with PDB and chemical PK fertilizer on the yield of roselle was significant as compared to RP alone. The mean comparison of data in different treatments (Table 4) showed that the highest yield was achieved by application of RP at the rates of 200 and $250 \mathrm{~kg} / \mathrm{fed}+$ PDB treatments. Among rock phosphate treatments, the highest number of fruits, weight of fresh fruits, weight of fresh and dry sepals/plant and expected weight of dry sepals kg /fed of Hibiscus sabdariffa L were scored by application of $200 \mathrm{~kg} /$ fed RP+PDB treatment, and also the same treatment gave the highest seeds yield (79.67 and 78.60) in the first and second seasons, respectively, (Table 5). From the explaination; phosphate solubilizing bacteria (Bacillus polymyxa) release organic and inorganic acids which reduce soil $\mathrm{pH}$ leading to change of phosphorus and other nutrients to available forms ready for uptake by plants (Singh and Kapoor,1999). Akande et al. (2011) reported that application of ogun rock phosphate (ORP) as a source of P, either amended or un-amended improves the growth and seed yield of kenaf (Hibiscus cannabinus L.).

\section{c- Effect of Rock phosphate (RP) on acidity and anthocyanin content of roselle:}

The results in Table (5) showed that all the fertilization treatments significantly increased quality of calyces including anthocyanin contents and acidity \%, compared with the values recorded for the plants treated with RP alone, giving the least value. The highest acidity and anthocyanin content (29.24\%, $62.21 \mathrm{mg} / \mathrm{g}$ and $26.77 \%$, $62.49 \mathrm{mg}$ ) in the first and the second seasons were determined in case of applying chemical PK fertilizer and $200 \mathrm{~kg} / \mathrm{fed}$ $\mathrm{RP}+\mathrm{PDB}$, respectively. In the same line, Sakr et al. (2014) reported that results obtained from any fertilization treatment (chemical PK, rock phosphate and feldspar fertilizers) in combination with inoculation by the mixture of biofertilizers containing Bacillus megaterium var. phosphaticum and 
Table 4. Effect of chemical and rock phosphate fertilizers with or without bio-fertilizers on number of fruits/plant, weight of fresh fruits/plant, weight of fresh and dry sepals/plant and weight of dry sepals /fed of Hibiscus sabdariffa L. during 2013 and 2014seasons.

\begin{tabular}{|c|c|c|c|c|c|c|c|c|c|c|}
\hline \multirow{2}{*}{ Treatments } & \multicolumn{2}{|c|}{$\begin{array}{l}\text { Number of } \\
\text { fruits/plant }\end{array}$} & \multicolumn{2}{|c|}{$\begin{array}{l}\text { Weight of fresh } \\
\text { fruits (g/plant) }\end{array}$} & \multicolumn{2}{|c|}{$\begin{array}{l}\text { Weight of fresh } \\
\text { sepals (g/plant) }\end{array}$} & \multicolumn{2}{|c|}{$\begin{array}{l}\text { Weight of dry } \\
\text { sepals ( g/plant) }\end{array}$} & \multicolumn{2}{|c|}{$\begin{array}{l}\text { Weight of dry } \\
\text { sepals (kg/fed) }\end{array}$} \\
\hline & $\begin{array}{c}\text { Season } \\
1\end{array}$ & $\begin{array}{c}\text { Season } \\
2 \\
\end{array}$ & $\begin{array}{c}\text { Season } \\
1\end{array}$ & $\begin{array}{c}\text { Season } \\
2 \\
\end{array}$ & $\begin{array}{c}\text { Season } \\
1\end{array}$ & $\begin{array}{l}\text { Season } \\
2 \\
\end{array}$ & $\begin{array}{c}\text { Season } \\
1\end{array}$ & $\begin{array}{l}\text { Season } \\
2 \\
\end{array}$ & $\begin{array}{c}\text { Season } \\
1\end{array}$ & $\begin{array}{c}\text { Season } \\
2 \\
\end{array}$ \\
\hline PK & 89.70 & 88.57 & 450.00 & 437.80 & 310.30 & 311.87 & 36.07 & 35.33 & 565.53 & 554.03 \\
\hline RP1+PDB & 87.87 & 84.33 & 445.00 & 423.43 & 314.43 & 296.93 & 35.20 & 33.10 & 551.94 & 519.01 \\
\hline RP2+PDB & 98.37 & 93.87 & 490.40 & 469.77 & 347.93 & 333.20 & 39.53 & 37.50 & 619.88 & 588.00 \\
\hline RP3+PDB & 95.10 & 91.13 & 480.07 & 464.83 & 341.90 & 325.83 & 37.70 & 36.13 & 591.13 & 566.57 \\
\hline RP2 & 84.43 & 81.83 & 366.70 & 350.30 & 262.43 & 253.63 & 29.90 & 28.27 & 468.83 & 443.22 \\
\hline L.S.D.at5\% & 2.95 & 2.73 & 7.11 & 3.94 & 6.27 & 5.82 & 1.25 & 0.89 & 19.65 & 14.03 \\
\hline
\end{tabular}

RP: Rock phosphate, F: Feldspar, PDB: Phosphate dissolving bacteria, and KDB: Potassium dissolving bacteria.

Table 5. Effect of chemical and rock phosphate fertilizers with or without bio-fertilizers on weight of seeds/plant, total Anthocyanin content $(\mathrm{mg} / \mathrm{g})$ and Acidity\% in dry sepals of Hibiscus sabdariffa $\mathrm{L}$. during 2013 and 2014 seasons.

\begin{tabular}{lcccccc}
\hline \multirow{2}{*}{ Treatments } & \multicolumn{2}{c}{ Weight of seeds (g/plant) } & \multicolumn{2}{c}{ Anthocyanin content } & \multicolumn{2}{c}{ Acidity\% } \\
& Season & Season & Season & Season & Season & Season \\
& $\mathbf{1}$ & $\mathbf{2}$ & $\mathbf{1}$ & $\mathbf{2}$ & $\mathbf{1}$ & $\mathbf{2}$ \\
\hline PK & 73.17 & 69.87 & 61.77 & 62.21 & 29.24 & 28.07 \\
RP1+PDB & 70.93 & 65.97 & 59.21 & 60.40 & 25.78 & 25.73 \\
RP2+PDB & 79.67 & 78.60 & 61.26 & 62.49 & 26.77 & 26.19 \\
RP3+PDB & 75.57 & 75.73 & 60.34 & 61.28 & 25.77 & 25.88 \\
RP2 & 67.40 & 63.60 & 59.15 & 60.40 & 24.89 & 25.45 \\
L.S.D.at5\% & 2.92 & 3.31 & 1.17 & 0.87 & 1.58 & 1.41 \\
\hline
\end{tabular}

RP: Rock phosphate, F: Feldspar, PDB: Phosphate dissolving bacteria, and KDB: Potassium dissolving bacteria.

Bacillus mucilaginosus were better, than the use of the same fertilization treatment alone and improving the quality of calyces of roselle plants.

\section{2-Potassium fertilization experiment:}

a- Effect of feldspar (F) on the growth of roselle:

The data in Table (6) showed that, complementary applications of feldspar with biofertilizers, increased significantly all of vegetative characters of roselle plants (plant height, number of branches, number of fruits and weight of fresh and dry plant) comparing to the other treatments in both years. The highest values were recorded for the application of 350 and $450 \mathrm{~kg} /$ fed rock potassium with biofertilizers respectively. The obtained data are in agreement with those reported by Abou-el-Seoud and AbdelMegeed (2012). Badr et al. (2006), they found that the dry matter of sorghum plants inoculated with silicate dissolving bacteria (SBS strain) and supplied with minerals (feldspar and rock phosphate) were increased by $48 \%, 65 \%$ and $58 \%$ for clay, sandy and calcareous soil, respectively moreover potassium uptake had been improved markedly with inoculation of bacteria in the 
Table 6. Effect of chemical and feldspar fertilizers with or without bio-fertilizers on plant height, root length, number of branches/plant, number of fruits/plant and weight of fresh and dry of plant/plant of Hibiscus sabdariffa L. during 2013 and 2014seasons.

\begin{tabular}{|c|c|c|c|c|c|c|c|c|c|c|}
\hline \multirow{2}{*}{ Treatments } & \multicolumn{2}{|c|}{ Plant height $(\mathrm{cm})$} & \multicolumn{2}{|c|}{ Root length (cm) } & \multicolumn{2}{|c|}{$\begin{array}{c}\text { Number of } \\
\text { branches/plant }\end{array}$} & \multicolumn{2}{|c|}{$\begin{array}{c}\text { Plant fresh } \\
\text { weight (g/plant) }\end{array}$} & \multicolumn{2}{|c|}{$\begin{array}{l}\text { Plant dry weight } \\
\text { (g/plant) }\end{array}$} \\
\hline & $\begin{array}{c}\text { Season } \\
1\end{array}$ & $\begin{array}{l}\text { Season } \\
2\end{array}$ & $\begin{array}{c}\text { Season } \\
1\end{array}$ & $\begin{array}{l}\text { Season } \\
2\end{array}$ & $\begin{array}{c}\text { Season } \\
1\end{array}$ & $\begin{array}{c}\text { Season } \\
2 \\
\end{array}$ & $\begin{array}{c}\text { Season } \\
1\end{array}$ & $\begin{array}{c}\text { Season } \\
2\end{array}$ & $\begin{array}{c}\text { Season } \\
1\end{array}$ & $\begin{array}{c}\text { Season } \\
2 \\
\end{array}$ \\
\hline PK & 168.87 & 166.97 & 37.20 & 39.63 & 19.40 & 20.30 & 872.00 & 890.00 & 186.27 & 190.30 \\
\hline RP1+PDB & 163.70 & 160.03 & 35.97 & 38.17 & 18.60 & 19.50 & 827.00 & 832.30 & 181.13 & 187.53 \\
\hline RP2+PDB & 178.53 & 177.10 & 44.00 & 46.93 & 22.17 & 23.20 & 954.70 & 935.30 & 201.47 & 196.80 \\
\hline RP3+PDB & 167.43 & 173.03 & 42 & 7 & 19.60 & 20.47 & 944.30 & 932.00 & 199.13 & 195.77 \\
\hline RP2 & 162.13 & 157.73 & 35.70 & 35.93 & 17.33 & 17.93 & 734.90 & 748.70 & 166.63 & 174.20 \\
\hline L.S.D.at5\% & 4.62 & 4.48 & 3.12 & 2.07 & 1.21 & 1.01 & 12.32 & 16.97 & 4.47 & 2.59 \\
\hline
\end{tabular}

RP: Rock phosphate, F: Feldspar, PDB: Phosphate dissolving bacteria, and KDB: Potassium dissolving bacteria.

tested soils as compared to the corresponding controls, for the plants supplied with minerals alone. And also Han et al. (2006) reported that application of (RP+ PDB) and (RK +KDB) increased the growth by about $38 \%$ and $28 \%$, respectively, compared with the control.

\section{b- Effect of feldspar (F) on yield of roselle:}

With respect to yield parameters the results (Table7) revealed that the application of chemical fertilizer and feldspar with biofertilizer significantly affected on most characters at $5 \%$ probability level as compared to feldspar without bio-fertilizer. With respect to sepals, data presented that the highest yield was obtained in case of application of the recommended dose of (PK) chemical fertilizers and feldspar plus KDB treatments. While the application of $350 \mathrm{~kg} / \mathrm{fed}+\mathrm{KDB}$ resulted in the highest increase in dry sepals yield (g/plant) and the expected weight of sepals ( $\mathrm{kg} / \mathrm{fed})$, giving $38.58 \mathrm{~g} / \mathrm{plant}$ and $604.93 \mathrm{~kg} / \mathrm{fed}$, respectively) comparing with the other treatments. The interactions effect of biofertilizer and feldspar was significant on seeds yield. The addition of $350 \mathrm{~kg} / \mathrm{fed}$ feldspar + KDB treated plants resulted in significantly the highest yield of seeds (71.61 and $73.97 \mathrm{~g} /$ plant in the first and second season, respectively) as compared with the plants unamended with feldspar (Table 8). In the same line Shaalan (2005) on Nigella sativa and Sakr et al. (2014) on Hibiscus sabdariffa showed that biofertilizers treatments promoted the growth and increased the yield of the plant. This increase might be attributed to the fact that KDB release organic acids, which solubilize the insoluble rock K materials (Friedrich et al., 1991; Ullman et al., 1996). Similarly, Styriakova et al. (2003) reported that the activity of potassium dissolving bacteria played a pronounced role in the release of $\mathrm{K}$ from feldspar.

\section{c- Effect of feldspar (F) on acidity and anthocyanin content of roselle:}

The obtained results in Table (8) show that there were significant increase in the total anthocyanin content and total acidity of sepals as a results of PK chemical fertilizer treatment and feldspar plus biofertilizer comparing to the plants treated with feldspar alone. The highest anthocyanin content and acidity \% were found in case of applying PK chemical fertilizer and $350 \mathrm{~kg} /$ fed feldspar plus biofertilizer, respectively. In the same line Sakr et al. (2014) reported that any fertilization treatment (chemical PK, rock phosphate and feldspar fertilizers) in 
Table 7. Effect of chemical and rock phosphate fertilizers with or without bio-fertilizers on number of fruits/plant, weight of fresh fruits/plant, weight of fresh and dry sepals (g/plant) and weight of dry sepals (kg/fed) of Hibiscus sabdariffa $\mathrm{L}$. during 2013 and 2014 seasons.

\begin{tabular}{|c|c|c|c|c|c|c|c|c|c|c|}
\hline \multirow[b]{2}{*}{ Treatments } & \multicolumn{2}{|c|}{$\begin{array}{l}\text { Number of } \\
\text { fruits/plant }\end{array}$} & \multicolumn{2}{|c|}{$\begin{array}{l}\text { Weight of fresh } \\
\text { fruits (g/plant) }\end{array}$} & \multicolumn{2}{|c|}{$\begin{array}{l}\text { Weight of fresh } \\
\text { sepals (g/plant) }\end{array}$} & \multicolumn{2}{|c|}{$\begin{array}{l}\text { Weight of dry } \\
\text { sepals (g/plant) }\end{array}$} & \multicolumn{2}{|c|}{$\begin{array}{l}\text { Weight of dry } \\
\text { sepals (kg/fed) }\end{array}$} \\
\hline & $\begin{array}{c}\text { Season } \\
1\end{array}$ & $\begin{array}{l}\text { Season } \\
2\end{array}$ & $\begin{array}{c}\text { Season } \\
1\end{array}$ & $\begin{array}{c}\text { Season } \\
2\end{array}$ & $\begin{array}{c}\text { Season } \\
1\end{array}$ & $\begin{array}{c}\text { Season } \\
2\end{array}$ & $\begin{array}{c}\text { Season } \\
1\end{array}$ & $\begin{array}{c}\text { Season } \\
2\end{array}$ & $\begin{array}{c}\text { Season } \\
1\end{array}$ & $\begin{array}{c}\text { Season } \\
2\end{array}$ \\
\hline PK & 79.93 & 81.30 & 399.90 & 395.20 & 296.57 & 283.53 & 35.50 & 32.50 & 556.69 & 509.64 \\
\hline RP1+PDB & 73.93 & 72.47 & 376.60 & 367.50 & 260.40 & 263.37 & 30.15 & 30.37 & 472.80 & 476.15 \\
\hline RP2+PDB & 87.07 & 89.67 & 431.20 & 423.00 & 303.63 & 300.43 & 38.58 & 37.64 & 604.93 & 590.19 \\
\hline RP3+PDB & 84.97 & 81.80 & 424.40 & 414.60 & 302.20 & 296.73 & 38.02 & 35.72 & 584.72 & 549.35 \\
\hline RP2 & 62.53 & 70.27 & 331.50 & 342.30 & 233.67 & 247.87 & 27.92 & 28.57 & 437.84 & 448.03 \\
\hline L.S.D.at5\% & 2.58 & 2.85 & 7.11 & 7.87 & 3.43 & 4.99 & 1.13 & 0.57 & 17.60 & 9.02 \\
\hline
\end{tabular}

RP: Rock phosphate, F: Feldspar, PDB: Phosphate dissolving bacteria, and KDB: Potassium dissolving bacteria.

Table 8. Effect of chemical and rock phosphate fertilizers with or without bio-fertilizers on weight of seeds/plant, total anthocyanin content $(\mathrm{mg} / \mathrm{g})$ and Acidity\% in dry sepals of Hibiscus sabdariffa L. during 2013 and 2014 seasons.

\begin{tabular}{lcccccc}
\hline \multirow{2}{*}{ Treatments } & \multicolumn{2}{c}{ Weight of seeds (g/plant) } & \multicolumn{2}{c}{ Anthocyanin content } & \multicolumn{2}{c}{ Acidity\% } \\
& $\begin{array}{c}\text { Season } \\
\text { 1 }\end{array}$ & $\begin{array}{c}\text { Season } \\
\mathbf{2}\end{array}$ & $\begin{array}{c}\text { Season } \\
\mathbf{1}\end{array}$ & $\begin{array}{c}\text { Season } \\
\mathbf{2}\end{array}$ & $\begin{array}{c}\text { Season } \\
\mathbf{1}\end{array}$ & $\begin{array}{c}\text { Season } \\
\mathbf{2}\end{array}$ \\
\hline PK & 64.23 & 63.28 & 62.77 & 62.87 & 28.22 & 28.89 \\
RP1+PDB & 64.72 & 64.59 & 60.48 & 59.41 & 26.82 & 26.28 \\
RP2+PDB & 71.61 & 73.97 & 61.99 & 60.92 & 28.33 & 27.50 \\
RP3+PDB & 66.87 & 71.37 & 60.82 & 59.91 & 27.44 & 27.51 \\
RP2 & 57.17 & 56.94 & 58.12 & 59.24 & 25.69 & 25.92 \\
L.S.D.at5\% & 1.94 & 1.35 & 1.64 & 1.27 & 1.28 & 0.06 \\
\hline RP: Ro & & & & &
\end{tabular}

RP: Rock phosphate, F: Feldspar, PDB: Phosphate dissolving bacteria, and KDB: Potassium dissolving bacteria.

combination with inoculation of the biofertilizers mixture containing Bacillus megaterium var. Phosphaticum and Bacillus mucilaginosus were more effective than using of the same fertilization treatment alone on improving quality of calyces.

\section{CONCLUSION}

It can be concluded from the results that, inoculation of PDB and KDB in conjunction with the direct application of rock phosphate and feldspar materials into the soil significantly increased the plant growth, sepals yield and quality of roselle plants grown on calcareous soils. The application of these bio-inoculants not only helps in the solubilization of the fixed $\mathrm{P}$ in rock Phosphate and $\mathrm{k}$ in feldspar but also reduce the amount of costly prepared chemical fertilizers being applied to the soil, thereby providing a cheaper and sustainable source of phosphorus and potassium for the plants and obtaining safe and high quality product.

\section{REFERENCES}

Abou-Aly, H.E.; Mady, M.A. and Moussa, S.A.M. (2006). Interaction effect between phosphate dissolving microorganisms and boron on growth, endogenous phytohormones and yield of 
squash (Cucurbita pepo L.). The First Scientific Conference of the Agriculture Chemistry and Environment Society, Cairo, Egypt.

Abou-el-Seoud, A. and Abdel-Megeed (2012). Impact of rock materials and biofertilizations on $\mathrm{P}$ and $\mathrm{K}$ availability for maize (Zea Maize) under calcareous soil conditions. Saudi Journal of Biological Sciences, 19(1):55-63.

Adepetu, J. A. (1986). Soil fertility and fertilizer requirement in Oyo, Ogun and Ondo states of Nigeria. Federal Ministry of Agriculture and Water Resources (publ.), Lagos.

Akande, M.O.; Adediran, J.A.; Oluwatoyinbo, F.I.; Makinde, E.A. and Adetunji, M.T. (2008). Suitability of poultry manure amended Sokoto rock phosphate on growth, nutrient uptake and yield of chilli pepper (Capsicum fruitscens L). Niger. J. Soil Sci., 18:167174.

Akande, M.O.; Makinde, E.A.; Aluko, O.A.; Oluwatoyinbo, F.I. and Adediran, J.A (2011). Rock phosphate amendment effects on Kenaf (Hibiscus cannabinus) growth and yield. Tropical and Subtropical Agroeco systems, 14(2):559565.

Alexander, M. (1997). Introduction to Soil Microbiology, second ed. John Wiley \& Sons Inc., New York.

Badr, M.A.; Shafei, A.M. and Sharaf ElDeen, S.H. (2006). The dissolution of $\mathrm{K}$ and P-bearing minerals by silicate dissolving bacteria and their effect on sorghum growth. Res. J. Agric. Biol .Sci., 2(1):5-11.

Balasubramanian, V.; Nnadi, I.A.; Lombin, G.I. and Yayock, Y.A. (1978). Fertilizer use in Nigeria. II. Future prospects and problems. Samaru Conference Paper No 32 IAR, Samaru, Nigeria.

Black, C.A.; Evans, D.D.; Nhite, J.I.; Ensminger, L.E. and Clark, F.E. (1982).
Methods of Soil Analysis. J. Amer. Soc. Agron. Inc. Madison, Wisconsin U.S.A.

Caravaca, F; Alguacil, M.M.; Azcon, R.; Diaz, G. and Roldan, A. (2004). Comparing the effectiveness of mycorrhizal inoculum and amendment with sugar beet, rock phosphate and Aspergillus niger to enhance field performance of the leguminous shrub Dorycnium pentaphyllum L. Applied Soil Ecology, 25(2):169-180.

Diab, M.A. (1968). The Chemical Composition of Hibiscus sabdariffa. M.Sc. Thesis, Fac. Agric, Cairo Univ.

Due, C.T. and Francis, F.J. (1973). Anthocyanins of roselle (Hibiscus sabdariffa, L.). Journal of food Science, 38(5):810-812.

El-Habbasha, S.F.; Hozayn, M. and Khalafallah, M.A. (2007). Integration effect between phosphorus levels and biofertilizers on quality and quantity yield of faba bean (Vicia faba L.) in newly cultivated sandy soils. Res. J. Agric Biol Sci., 3(6):966-971.

Eltayeib, A.A. and Hamade, H. (2014). Phytochemical and chemical composition of water extract of Hibiscus sabdariffa (Red Karkade Calyces) in North Kordofan State-Sudan International Journal of Advanced Research in Chemical Science, 1(6):10-13.

Eweda, W.E.; Selim, S.M.; Mostafa, M.I. and Abd El-Fattah, D.A. (2007). Use of Bacillus circulans as bio-accelerator enriching composted agricultural wastes identification and utilization of the microorganism for compost production. In: Proceedings of the $12^{\text {th }}$ Conference of the Microbiology. Organized by The Egyptian Soc. of App. Micro. (ESAM), Giza, Egypt, 18(20):43-65.

Friedrich, S.; Platonova, N.P.; Karavaiko, G.I.; Stichel, E. and Glombitza, F. (1991). Chemical and microbiological solubilization of silicates. Acta Biotech., 11:187-196. 


\section{A.A.S. Abdel-Kader and F.E.M. Saleh}

Fuleki, T. and Fransis, F.J. (1968). Quantitative methods of anthocyanins, 1. Extraction and determination of anthocyanin in cranberries, J. of Food Sci., 33(1):72.

Gerke, L. (1992). Phosphate, aluminum, and iron in the soil solution of three different soils in relation to varying concentrations of citric acid. Zeitschrift für Pflanzenernährung und Bodenkunde., 155:339-343.

Girgis, M.G.Z. (2006). Response of wheat to inoculation with phosphate and potassium mobilizers and organic amendment. Ann. Agric. Sci. 51(1):85100.

Han, H.S.; Supanjani, E. and Lee, K.D. (2006). Effect of co-inoculation with phosphate and potassium solubilizing bacteria on mineral uptake and growth of pepper and cucumber. Plant Soil Environ., 52(3):130-136.

Ibrahim, H.I.M.; Zaglol, M.M.A. and Hammad, A.M.M. (2010). Response of balady guava trees cultivated in sandy calcareous soil to biofertilization with phosphate dissolving bacteria and/or VAM fungi. J. Am. Sci., 6(9):399-404.

Jackson, M.L. (1973). Soil Chemical Analysis. Prentice-Hal Inc., Engiewood Cliffs, New Jersey.

Mahfouz, S.A. and Sharaf-Eldin, M.A. (2007). Effect of mineral vs. biofertilizer on growth, yield and essential oil content of fennel (Foeniculum vulgare Mill.). International Agrophysics, 21(4):361366.

Morton, F.J. (1974). Renewed Interest In Roselle (Hibiscus Sabdariffa L.) The Long- Forgotten "Florida Cranberry" Morton Collectanea, University Of Miamicoral Gables Florida State Horticultural Society, 415-425.

Nahas, E.; Banzatto, D.A. and Assis, L.C. (1990). Fluorapatite solubilization by Aspergillus niger in vinasse medium. Soil Biol. Biochem. (22):1097-1101.
Osuntgum, B. and Aboaba, O.O. (2004). Microbiological and physio-chemical evaluation of some none-alcoholic beverages. Pakistan. J. Nut., 3(3):188192.

Parassana, A.; Deepa, V.; Murthy, P.B.; Deecaraman, M.; Sridhar, R. and Dhandapani, P. (2011). Insoluble phosphate solubilization by bacterial strains isolated from rice rhizosphere soils from Southern India. International Journal of Soil Science, 6(2):134-141.

Puente, M.E.; Bashan, Y. and Lebsky, V.K. (2004). Microbial population and activities in rhizoplane of rockweathering desert plants, I. Root colonization and weathering of igneous rocks. Plant Biology, (6):629-642.

Ranawat, P.; Kumar, K.M. and Sharma, N.K. (2009). A process for making slowrelease phosphate fertilizer from lowgrade rock phosphate and siliceous tailings by fusion with serpentinite. Curr. Sci., 96(6):843-848.

Rodriguez, H. and Fraga, R. (1999). Phosphate solubilizing bacteria and their role in plant growth promotion. Biotech. Adv., 17(4):319-339.

Sakr, W.R.A.; Elbagoury, H.M.; Sidky, M.A. and Ali, S.A. (2014). Production of organic roselle by natural minerals and biofertilizers. American-Eurasian J. Agric. \& Environ. Sci., 14(10):985-995.

Shaalan, M.N. (2005). Influence of biofertilizers and chicken manure on growth, yield and seeds quality of Nigella sativa L. plants. Egypt. J. Agric. Res., 83:811-828.

Sheng, X.F. and Huang, W.Y. (2002). Mechanism of potassium release from feldspar affected by the strain NBT of silicate bacterium. Acta Pedol. Sin., 39(6):863-871.

Sheng, X.F.; He, L.Y.and Huang, W.Y. (2002). The conditions of releasing potassium by a silicate-dissolving 
bacterial strain NBT. Agric. Sci. China, 1(6): 662-666.

Shivay, Y.S. (2010). Effect of diammonium phosphate and mussoorie rock phosphate on productivity and economics of potato (Solanum tuberosum). Indian J. Agric. Sci., 80(4):329-332.

Singh, S. and Kapoor, K.K. (1999). Inoculation with phosphate solubilizng microorganisms and a vesicular mycorrhizal fungus improves dry matter yield and nutrient uptake by wheat grown in a sandy soil. Biol. Fert. Soils, 28(2):139144.

Snedecor, G.W. and Cochran, W.G. (1973). Statistical Methods. Sixth Edition, Iowa State Univ. Press, Ames, Iowa, USA.

Steel, R.G.D. and Torrie, J.H. (1982). Principles and Procedures of Statistics. $3^{\text {rd }}$ Edn., McGraw-Hill International Book Co., London.

Styriakova, I.; Styriak, I.; Galko, I.; Hradil, D. and Bezdicka, P. (2003). The release of iron-bearing minerals and dissolution of feldspar by heterotrophic bacteria of Bacillus species. Acta Pedol. Sin., 47(1):20-26.
Tribor, F. and Fransis, F.J. (1968). Quantitative methods for anthocyanins, 1. Extraction and determination of total anthocyanin in cranberries. J. of Food Sci., 33(1):72-77.

Ullman, W.J.; Kirchman, D.L. and Welch, S.A. (1996). Laboratory evidence for microbially mediated silicate mineral dissolution in nature. Chem. Geol., 132(1):11-17.

Yosefi, K.; Galavi, M.; Ramrodi, M. and Mousavi, S.R. (2011). Effect of biophosphate and chemical phosphorus fertilizer accompanied with micronutrient foliar application on growth, yield and yield components of maize (Single Cross 704). Aust. J. Crop Sci., 5(2):175-180.

Zakaria, A.A.B. (2009). Growth Optimization of Potassium Solubilizing Bacteria Isolated from Biofertilizer. Bachelor of Chem. Eng.(Biotech.), Fac. of Chem., Natural Resources Eng. Univ., Malaysia Pahang, p.40.

Zapata, F. and Roy, R.N. (2004). Use of Phosphate Rock for Sustainable Agriculture. FAO and IAEA, Rome, Italy.

\section{تحسين إنتاج وجودة نبات الكركديه بإستخدام المصادر الطبيعية للقوسفور والبوتاسيوم فى الاراضى الرملية الجيرية المية الطية}

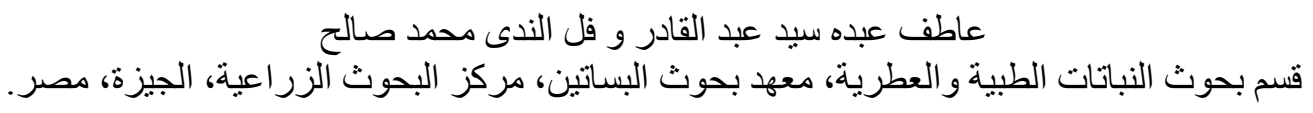

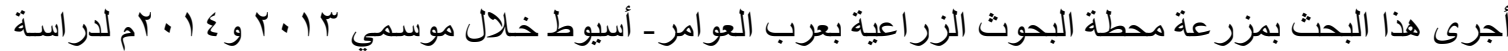

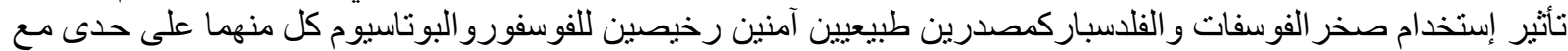

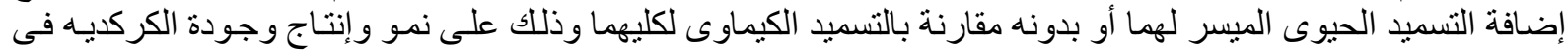

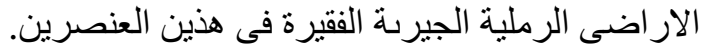

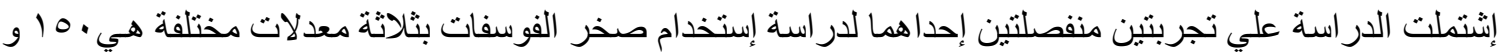

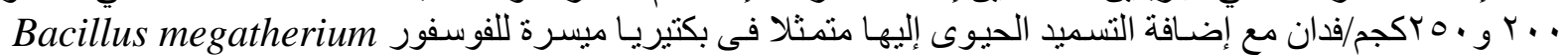

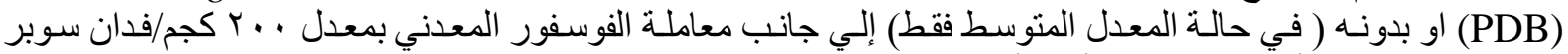

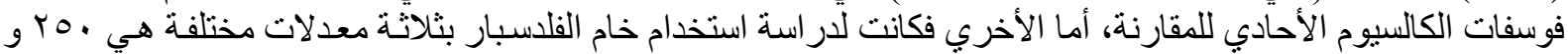

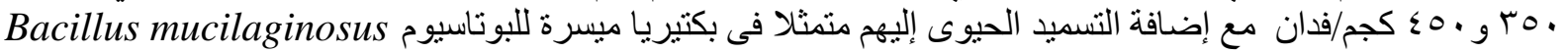

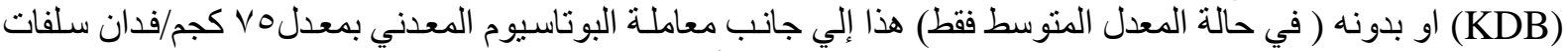
بوتاسيوم للمقارنة. وقد تم تحليل النتائج المتحصل عليها إحصائيا وأظهرت الآتي : 


\section{A.A.S. Abdel-Kader and F.E.M. Saleh}

بصفة عامة أدي استخدام أي من معدلات صخر الفوسفات او الفلدسبار سالفة الذكر مع اضافة الفيات السماد الحيوي المبسر

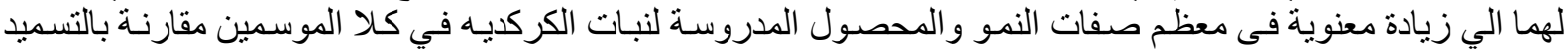

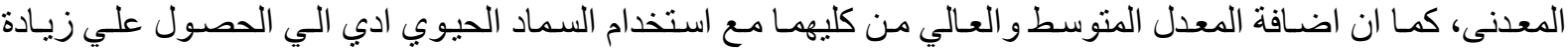

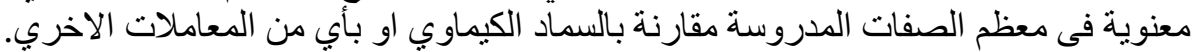

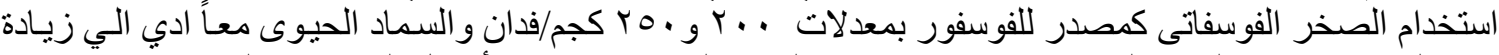

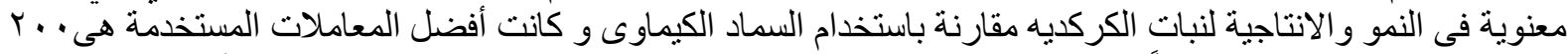



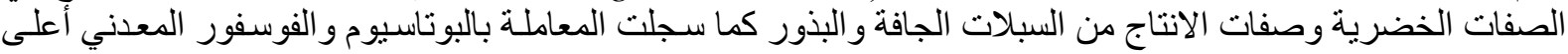

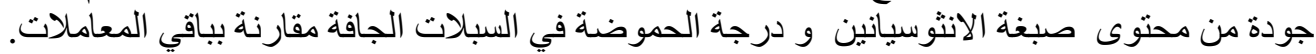

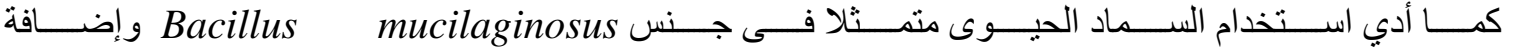



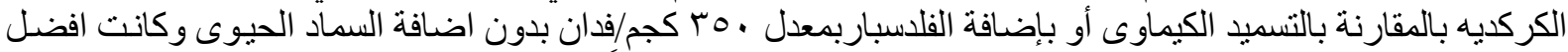

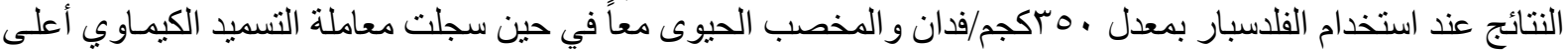

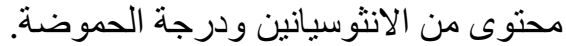



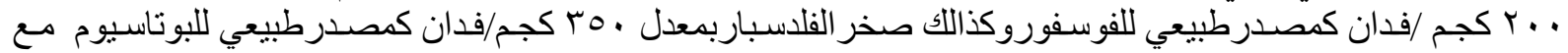
إستخدام البكتيرسا الميسرة لكليهماً. 